\title{
From the other side of the fence. How civil society and patients see prison healthcare
}

\author{
Espacio R
}

Chair of CESIDA (State Coordinating Body of HIV and AIDS).

The spread of the human immunodeficiency virus (HIV) and AIDS in the mid-eighties was an organisational and operational challenge for the Spanish National Health System (SNS), particularly for prison healthcare. The problem reached its climax in 1994, when 763 cases of AIDS were declared and more than 400 inmates died from AIDS-related complications in prisons run by the Civil Service (AGE) ${ }^{1}$. This figure includes both inmates inside centres and those who died while on probation or on leave. Taking into consideration the size of the prison population at the time, these figures mean that one out of every 50 inmates developed AIDS, and that there was a prevalence of infection by HIV of $22 \%$, or rather, almost one in four inmates.

The impact of this new disease on prison healthcare is undeniable. Since then, a collaborative structure of interests has been built between prison health workers and non-governmental organisations (NGO) to respond to HIV and AIDS. Together, we have achieved great things; the implementation of opiate substitute and needle exchange programs in prisons are just two examples of our work. Another achievement is the exponential growth in the presence and provision of services by NGOs.

We have more recent examples of successful collaborations between healthcare professionals and the associations movement organised around the issues of HIV and viral hepatitis. Such a collaboration has been essential in ensuring the dispensation of direct action antivirals against hepatitis $\mathrm{C}$ in all the prisons of the Valencia region.

Associations, especially those operating in the field of healthcare, are the natural allies of prison health workers, because we share the same aim, which is none other than to enable inmates to receive medical care that is on a par with other citizens. Furthermore, civil society has more freedom in accessing healthcare administrations and the media. However, this collaboration is frequently limited to the volunteer work of one local clinic and an NGO that is informally coordinated to work on one common objective.

One result of this spirit of collaboration is the assignment I have received from this magazine as chair of the State Coordinating Body of HIV and AIDS Associations (CESIDA) to write this editorial in which I shall set out to answer the following questions: What are the main problems of prison health today? How is it perceived by patients and entities in civil society? And how could it be improved?

To prepare this article, I drew up a small questionnaire for entities of the CESIDA that implement programs in prisons, and held some interviews with inmates on day release or probation. I shall then show the results of this small piece of research that, despite lacking any pretensions of scientific rigour, has given me a broader perspective on these issues.

One problem that bodies in the CESIDA most frequently comment on when answering the questionnaire is the lack of communication with medical staff, especially with the doctors. Although there are many differences between prisons, the interlocutor for entities is usually the Treatment Department. This situation improves in activities linked to mental health and those geared towards persons included in the Programs for interdisciplinary care of the mentally ill (PAIEM), where there is more communication with medical coordinators in work such as selecting participants in health mediation training and in identifying persons for the PAIEM. However, it is also quite common for this coordination to be established more often with social workers or psychologists and less frequently with clinical practitioners.

We feel that there is a lot of room for improvement in this area, not just in the activities organised within the prisons themselves but also in the situation 
of prisoners on parole, day release or who have served their sentence. The isolation of the prison health system from regional health authority information systems, along with the high prevalence of mental illness and situations of social exclusion for inmates, creates a situation where the follow up of diseases as important as hepatitis C, HIV and mental illnesses is lost. We know of a number of interesting initiatives that work on the micro-elimination of hepatitis $\mathrm{C}$, where the efforts of NGOs to accompany persons in these situations has notably improved issues such as adherence and health outcomes. That is why we believe that establishing formal communication channels between medical practitioners and the professionals and/ or volunteers of NGOs would have a major impact on health care in the prison setting.

Another concern expressed by the persons interviewed is the lack of confidentiality shown when distributing medicines. For example, in an enclosed environment like the one existing in prisons, patients with HIV find themselves in situations where they cannot keep their serostatus a secret. Another commonly mentioned issue is the transfers that sometimes interrupt very important and costly treatments such as the one for hepatitis $\mathrm{C}(\mathrm{HCV})$. We have encountered a number of scandalous cases where, for reasons of conduct or potential danger, transfers were made against the opinion of the doctors, with serious consequences for inmates' health. Such situations are closely linked to the hierarchical system that exists within the state prison system.

In general terms, the opinion of inmates about the care and treatment they receive from medical personnel is positive. Members of organisations likewise value the efforts made by professionals to know more about subjects that fall outside their remit as doctors and professionals in primary health care. Nowadays, the medical practitioners of many Spanish prisons are real experts in the most prevalent infectious diseases in prisons, such as HIV, viral hepatitis and tuberculosis. We also know that their experience in managing mental diseases and substance addiction helps to counterbalance the scarce presence or total absence of specialists in some prisons.

In any case, we feel that the crisis that has been steadily emerging in recent years is due to the lack of medical personnel. Between 2012 and 2017, according to data from the General Secretariat of Penitentiary Institutions, the number of doctors attached to prisons run by the State dropped by about 15\% (from 437 to 372). At present, according to the most recent data available, the number of doctors is about 255 , which means a reduction of over $40 \%$. This drop in the number of staff is the biggest problem according to the answers in our questionnaire.

Prisons as important as Picassent in Valencia, the largest in Spain, currently has ${ }^{2}$ just five doctors, in comparison to the 16 working there in 2014 and the 23 established in the official jobs list as the ideal figure. The tangible consequences of this situation are that doctors can no longer provide primary care services and can only deal with emergency cases. This situation is not limited to clinical practitioners but also affects other healthcare workers. Worrying news was recently published about the complaints made by nursing staff about their work situation, the overload of work and the fact that they have to take on duties that go beyond their skills. They point out that the main problem is the mass retirement of doctors. According to statements by the Secretary General of the Professional Union of Prison Health José Veiras Right now the prisons find that more than $80 \%$ of doctors are over 55 years old. This is causing a progressive cascade of casualties due to retirement of doctors in prisons ${ }^{3}$ to take place in a few years. If we add the fact that the new vacancies that are announced are not being filled, then it is plain to see that this there are no short-term solutions to this situation.

In our opinion, the lack of staff is a direct consequences of the lack of compliance of national government, the regional administrations and the 2003 Cohesion Act, which gave a maximum period of 18 months to integrate the prison health system into the regional health systems [Sistemas Autonómicos de Salud (SAS)]. In a situation where there is a shortage of doctors in Spain, and with working conditions and remuneration way below the ones enjoyed by general practitioners in the SAS, then it is easy to understand why it is very difficult to find candidates for a career that, as vocational as it may be, is so undervalued.

Almost 15 years have gone by since the end of the term established to complete the integration process, and it has only taken place in the Basque Country and Catalonia, and even there the reasons for doing so may well be more political than functional or humanitarian. Over these 15 years we have seen many parliamentary questions and green papers presented by opposition parties that urged the central and regional governments of the day to initiate the processes necessary for integration. But when the very same parties win the elections, we see the same paralysis that they were so quick to denounce. What is evident is that the transfer of prison healthcare is not one of their priorities and neither is it an issue for mobilising public opinion and therefore winning votes. When we complain, we always hear the same 
excuse everywhere, it is the others who do not want to make any changes. Our strong feeling is that, as is so often the case, the problem is one of budgets and the lack of will of the Ministry of Home Affairs and prison directors because of their fear of losing the quota of power they have with the control of healthcare professionals.

We are aware that integration is not going to be an instant cure all, but simply by making the information systems containing the SAS clinical records compatible with those of the prison health system would resolve many of the problems that arise when people enter prison, and when they are released. The equalisation of working and pay conditions of prison health workers with those of their colleagues in the SAS would also do a lot to alleviate the current lack of generational replacement of medical professionals in prisons. However, given the current political climate, this solution shows little signs of being applied in the near future. Right now, prison healthcare is a sinking ship, and that is why it is essential to mobilise professionals and civil society in establishing urgent and imaginative measures to alleviate the problem, until a complete and rigorous process of transfer of powers finally takes place.

In answer to the question about civil society's and patients' vision of prison healthcare, a distinction has to be made between the perceptions of the professionals and how the system itself is seen. Those of us involved in organisations have a very high opinion of the work that medical professionals have done over the last decades in Spanish prisons, to the extent that their efforts went way beyond what was required of them as primary healthcare workers when working with many diseases. However, we do feel that prison healthcare, as a system in itself, should not hierarchically depend on the Ministry of Home Affairs, given the conflicts that arise when security issues are at odds with inmates' health needs.

We also feel that there is room for improvement in coordination between medical professionals and the organisations that assist the inmate population and ex-prisoners, both inside and outside prisons. As we mentioned above, we believe that we are natural allies because we share the same common objective of providing the best in care to the population we both work with.

Finally, we firmly believe that the integration process of prison healthcare into the SAS should be set in motion once and for all. This may well be the only way for the prison population to receive healthcare that is on a par with that of the general public. We have the example of the Basque Country, where the process was completed in just one year, which shows that, when there is a political will, it is not so very difficult to do. Another example is Catalonia, although it was probably easier there, since the powers regarding prisons had been transferred in 1984. Together we have to bail out the water to stop this ship from sinking, and by doing so prevent an increase in the morbidity/mortality of the prison population before it becomes irreversible.

\section{CORRESPONDENCE}

Ramón Espacio

E-mail: presidencia@cesida.org

\section{REFERENCES}

1. Dirección General de Instituciones Penitenciarias. Informe General de 2006. [Internet]. Madrid: Ministerio de Interior Secretaría técnica; 2006. [fecha de acceso: 16 Ene 2019]. Disponible en: http://www.institucionpenitenciaria.es/web/portal/documentos/publicaciones.html

2. Checa A. La falta de médicos en la cárcel de Picassent dispara el riesgo de agresiones a funcionarios. [Internet]. Las Provincias. 30 Jun 2018. [fecha de acceso: 16 Ene 2019]. Disponible en: https:// www.lasprovincias.es/comunitat/falta-medicoscarcel-20180701234814-ntvo.html

3. Los centros penitenciarios, "en crisis": la escasez de médicos va en aumento. [Internet]. El confidencial Autonómico. 15 mar 2018. [fecha de acceso: 16 Ene 2019]. Disponible en: https://autonomico.elconfidencialdigital.com/articulo/estado_autonomico/centros-penitenciarios-escasezmedicos-aumento/20180314185311020332.html 